\title{
Endothelial differentiation of Wharton's Jelly-derived mesenchymal stem cells seeded on chitosan/hyaluronan multilayer films
}

\author{
Hana Dennaoui ${ }^{1}$, Eliane Chouery ${ }^{2}$, Chaza Harmoush ${ }^{1}$ \\ Dr. Hana Dennaoui, Laboratory of Applied Biotechnology: \\ Biomolecules, Biotherapies and Bioprocesses, AZM Centre \\ for Biotechnology Research and its Applications, Doctoral \\ School of Science and Technology, Lebanese University, \\ El Mitein St, Tripoli, Lebanon
}

${ }^{1}$ Laboratory of Applied Biotechnology: Biomolecules, Biotherapies and Bioprocesses, AZM Centre for Biotechnology Research and its Applications, Doctoral School of Science and Technology, Lebanese University, Tripoli, Lebanon

${ }^{2}$ Medical Genetics Unit, Faculty of Medicine, Saint Joseph University (USJ), Mar Mikhaël, Beirut, Lebanon

E-mail: hana.dennaoui@hotmail.com

Citation: Dennaoui H, Chouery E, Harmoush C. Endothelial differentiation of Wharton's Jelly-derived mesenchymal stem cells seeded on chitosan/hyaluronan multilayer films. Cell Ther Transplant 2020; 9(4): 59-67.

\section{Summary}

The ease of harvesting of mesenchymal stem cells from Wharton's jelly (WJ-MSCs), their great differentiation plasticity and low immunogenicity make them a suitable tool for allogeneic cell therapy. The aim of present study was to explore the potential of WJ-MSCs seeded on chitosan/hyaluronic acid (HA/CHI) multilayers to differentiate into endothelial-like cells.

\section{Methods}

In this study, we differentiate WJ-MSCs into an angiogenic lineage using polyelectrolyte multilayer film as a substrate. WJ-MSCs were cultivated on HA/CHI multilayer film and stimulated (or not) with EGM- $2^{\circ}$ culture medium. Type I collagen was used as control. mRNA and protein expression of CD31, vascular endothelial growth factor-receptor 2 (VEGF2) and vascular endothelial (VE)-cadherin, along with Dil-acetylated low-density lipoprotein-uptake and von Willebrand Factor protein expression were performed.

\section{Results}

The isolated MSCs showed typical fibroblast-like morphology. We have shown that WJ-MSCs express endothelial markers after 15 days of culture in EGM-2 ${ }^{\circ}$ medium. The mRNA levels were higher on $\mathrm{CHI} / \mathrm{HA}$ than on collagen for CD31 and KDR, with only KDR increase being statistically significant. At the protein level, a trend for increase in KDR and CDH5 levels was also shown on CHI/HA relative to collagen. Moreover, the WJ-MSCs seeded on CHI/HA showed a high fluorescence specific to von Willebrand factor after endothelial differentiation for 15 days.

\section{Conclusion}

We report here a new biocompatible coating allowing differentiation of WJ-MSCs into endothelial-like cells. This substrate opens new routes in tissue engineering to design allogeneic vascular grafts

\section{Keywords}

Mesenchymal stem cells, Wharton's jelly, differentiation, endothelial lineage, chitosan, hyaluronic acid, multilayer substrate, tissue engineering. 


\section{Introduction}

Cardiovascular diseases are the leading cause of human morbidity worldwide. Systemic atherosclerosis is considered to be one of the most common, severe, and life-threatening conditions [1]. Despite a variety of pharmaceutical and surgical treatment approaches to this pathology, they frequently lack the desired effectiveness. Since the beginning of the $21^{\text {st }}$ century, development of endovascular techniques has changed clinical indications and operative techniques in all the areas of vascular surgery. The classical bypass surgery, which required arterial substitutes, is now less used [2]. Hence, the goal of vascular research should be centered not on the search for an ideal arterial substitute, but on improving minimally invasive techniques such as cell therapy and regenerative medicine, aiming to develop new treatments of atherosclerosis in the near future.

Stem cell therapy is a novel and promising strategy which potentially is more effective than single-agent drug therapies for many diseases $[3,4]$. Stem cells function in the repair of injured tissues in two ways: by secretion of related cytokines [5], or by differentiating into the cell types at the site of injury, in order to exert its original function [6].

Multipotent mesenchymal stem cells (MSCs) which possess self-renewal potential and can differentiate into various cell types, such as osteoblasts, chondrocytes or adipocytes [7], may be isolated from adult tissues, including bone marrow, adipose tissue, and birth-associated tissues, such as placenta, umbilical cord, cord blood or amnion. MSCs are identified by three characteristics: (1) adherence to the culture dishes; (2) differentiation into osteoblasts, chondroblasts and adipocytes, and (3) expression of specific surface markers (CD90, CD105, CD73 and CD44), as well as lacking expression of several other markers including CD34 and HLA-DR [8-10].

Wharton`s jelly-derived MSCs (WJ-MSCs) have a high proliferation rate; they do not show any teratogenic, or carcinogenic behavior in case of transplantation [11]. The bone marrow and adipose tissue, among others, are, generally, used as sources of MSCs [7, 12]. Recent findings have shown that MSCs from human umbilical cord have advantages such as large numbers on harvest, strong proliferation and differentiation capacity and low immunogenicity compared to MSCs from the bone marrow [13].

Porous scaffolds prepared from natural polysaccharides are promising matrices for mimicking the in vivo ECM (extracellular matrix), since they resemble glycosaminoglycans (GAGs), which are essential ECM components [14]. Hyaluronic acid (HA) is a natural anionic polymer found in synovial fluid, skin, and cartilage, being among the major GAG components of brain ECM [15]. HA is used for diverse biomedical applications, due to its biocompatibility and water binding capacity $[16,17]$. Due to its remarkable hydrodynamic characteristics, particularly in terms of viscosity and ability to retain water, HA plays a significant role in assembly of extracellular and pericellular matrices by regulating their porosity and malleability [18].

The negative charge of HA hinders cell adhesion. Therefore, it is blended with other biomaterials to promote cell attach- ment [19]. Chitosan (CHI) is a widely used natural cationic polymer derived from crustacean shells that resembles GAGs, and has broad tissue engineering applications in view of its biocompatibility, biodegradability, hydrophilicity, low cost and availability [17]. The cationic nature of chitosan allows it to interact with negatively charged polymers and to form a polyelectrolyte complex (PEC) through ionic bonding [20].

Endothelial cells are one of the major components of the vessel wall, and these cells are important contributors to vascular tissue repair and regeneration [21]. The aim of present study was to explore the potential of WJ-MSCs seeded on $\mathrm{HA} / \mathrm{CHI}$ multilayers to differentiate into endothelial-like cells, by identifying and evaluating endothelial cell morphology, and studying endothelial cell-specific gene expression at mRNA and protein levels.

\section{Materials and methods}

\section{Polyelectrolytes multilayer films and collagen film}

Hyaluronic acid solution $(0.2 \mathrm{mg} / \mathrm{mL}$ in $\mathrm{NaCl} 0.15 \mathrm{M})$ and chitosan solution $(0.2 \mathrm{mg} / \mathrm{mL}$ in $\mathrm{NaCl} 0.15 \mathrm{M} / \mathrm{HCl} 2 \mathrm{mM})$ were used to produce the polyelectrolyte multilayers. Reagents were obtained from commercial sources and used without any further purification. Chitosan low-molecular weight and hyaluronan $(200 \mathrm{kDa})$ were obtained from Sigma Aldrich (Germany). Each experiment was preceded by a cleaning step of the cover glasses as follows: 15 min with 1\% sodium dodecyl sulfate (Sigma Aldrich, Germany) at $100^{\circ} \mathrm{C}$, extensive ultrapure water rinse, $15 \mathrm{~min}$ at $100^{\circ} \mathrm{C}$ with $0.1 \mathrm{M}$ $\mathrm{HCl}$ and, finally, cover glasses were thoroughly rinsed with ultrapure water. Coverslips were incubated in $\mathrm{CHI}$ solution for $5 \mathrm{~min}$, thoroughly washed in $\mathrm{NaCl}(0.5 \mathrm{M})$ and then incubated in HA solution for $5 \mathrm{~min}$. (CHIHA) ${ }_{10}$ films were built up after 20 alternate depositions of polycation and polynion layers. The type I collagen $(100 \mu \mathrm{g} / \mathrm{mL}$, purchased from BD Biosciences, France) was used as positive control for cellular adhesion. The collagen solution was added to the coverslips and incubated for 1 hour at room temperature. Then, the solution was carefully aspirated and the surface of glasses was rinsed 3 times with serum-free $\alpha$-MEM.

\section{Stem cell and mature endothelial cell isolation and culture}

Fresh human umbilical cords were obtained after full-term births with informed consent using the guidelines approved by the Hanan Hospital. Umbilical cord vessels were removed manually from cord segments, and the exposed Wharton's jelly was cut into very small pieces or explants. These explants were cultured in a-MEM (Lonza, Belgium) supplemented with $10 \%$ decomplemented fetal bovine serum (FBS), $2 \mathrm{mM}$ L-glutamine, $100 \mathrm{IU} / \mathrm{mL}$ Penicillin/streptomycin and $2.5 \mathrm{mg} / \mathrm{mL}$ Fungizon (Fisher, France) at $37^{\circ} \mathrm{C}$ and in $5 \% \mathrm{CO}_{2}$. At the fourth passage, WJ-MSCs were characterized by flow cytometry (FACSCalibur; BD Bioscience), as previously described [22], by assessing the expression of CD73, CD90, CD44, CD105, CD34, CD45 and HLA-DR, and then used in our experimental procedure. 
Human umbilical vein endothelial cells (HUVECs) were isolated according to the method of Jaffe et al. [23]. Briefly, the umbilical cords were washed in HBSS solution and HUVECs were extracted from umbilical cords veins using Trypsin. Then HUVECs were cultured at $37^{\circ} \mathrm{C}$ in $5 \% \mathrm{CO}_{2}$ in $25 \mathrm{~cm}^{2}$ tissue-culture-treated flask (suitable for cell attachment and growth) in complete medium. The medium consisted of an equal mixture of M199/RPMI 1640 media supplemented with $20 \%$ human serum albumin, $2 \mathrm{mM}$ L-glutamine, $20 \mathrm{mM}$ HEPES, $100 \mathrm{IU} / \mathrm{mL}$ Penicillin, $2.5 \mathrm{mg} / \mathrm{mL}$ Fungizon ${ }^{\oplus}$, being replaced every two days. The cells were used at the second passage culture and were seeded at $3 \times 10^{3} \mathrm{cells} / \mathrm{cm}^{2}$.

\section{Endothelial cell differentiation}

WJ-MSCs were seeded in 6-well plates at $3000 \mathrm{cells} / \mathrm{cm}^{2}$ on $\mathrm{CHI} / \mathrm{HA}$ or on COL-I coated glass substrates in a-MEM for 2 days. The unstimulated cells were then incubated in the complete Endothelial Basal Medium (EBM-2, Lonza ${ }^{\oplus}$, without growth factor supplements, whereas the stimulated were are incubated in complete Endothelial Growth Medium (EGM2, Lonza ${ }^{\circledR}$ supplemented with EPCs-differentiating medium) for 2 weeks.

As a negative control, the cells were cultured on glass in endothelial basal medium (EBM-2, Lonza ${ }^{\circledR}$ ) supplemented with $0.5 \%$ FBS. The culture medium was changed every 2 days. The cells cultured on both surfaces (glass and PEMs architectures) were observed daily by phase contrast microscopy (Leica) to check their morphology.

\section{Evaluation of endothelium-specific mRNA markers}

Transcript levels of CD31 (PECAM-1 platelet endothelial cell adhesion molecule), CDH5 (Vascular endothelial Cadherin) and KDR (VEGFR-2 vascular endothelial growth factor 2) genes were quantified by real-time qPCR. Total RNA were isolated with RNeasy mini kit (Qiagen, GmbH, Hilden, Germany) according to the manufacturer's instructions. Complementary DNA synthesis was performed with $350 \mathrm{ng}$ total RNA using iScript cDNA synthesis kit (Bio-Rad, USA). Real-time qPCR was conducted as described previously [24]. As a positive control, RNA isolated from human umbilical vein endothelial cells (HUVECs) was used. These cells were isolated from the umbilical cord veins and cultured in M199/ RPMI medium.

Measurement of gene expression was performed in duplicate; a non-template blank served as a negative control. qPCR was carried out using iQ SYBR ${ }^{\oplus}$ Green Supermix $\left(\right.$ Bio-Rad $\left.^{\oplus}\right)$ and in-home designed primers (using Primer3) for human CD31, VE-cadherin, VEGF-R2 and ribosomal protein. Forward and reverse primers (Eurogenetec) were as follows:

CD31: 5'-ATGATGCCCAGTTTGAGGTC-3';

5'ACGTCTTCAGTGGGGTTGTC-3',

KDR: 5'-GTGACCAACATGGAGTCGTG-3'; 5'TGCTTCACAGAAGACCATGC-3';

CDH5: 5'-CCTACCAGCCCAAAGTGTGT-3'; 5'-GACTTGGCATCCCATTGTCT-3';

RPS29: 5'-TCATCTTCCAGCCCAAATTC-3'; 5'-CTTGAACGGTTACCACCTCA-3'
PCR was performed with MyCycler ${ }^{\mathrm{Tm}}$ Personal Thermal Cycler $\left(\right.$ Bio-Rad $\left.{ }^{\star}\right)$. Cycling parameters were $3 \mathrm{~min}$ at $95^{\circ} \mathrm{C} ; 40$ cycles of $3 \mathrm{~min}$ at $60^{\circ} \mathrm{C}$ for CD31, VEGF-R2 and RP29 and $62^{\circ} \mathrm{C}$ for VE-cadherin and $1 \mathrm{~min}$ at $72^{\circ} \mathrm{C}$. The results were normalized to the housekeeping gene for S29 ribosomal protein. Analyses and fold differences were determined using the comparative CT method. The fold changes were calculated from the $\Delta \Delta C T$ values using the formula $2^{-\Delta \Delta C T}$, and the data were normalized relative to the reference gene values and then expressed as percentage of values obtained in $\mathrm{HU}$ VEC for each assayed mRNA.

\section{Detection of endothelium-specific protein markers}

Total proteins from cultured cells were prepared as previously described [26]. $25 \mu \mathrm{g}$ proteins from each sample were heated at $95^{\circ} \mathrm{C}$ for $5 \mathrm{~min}$ in Laemmli sample buffer (BioRad, USA), and the total proteins were separated in acrylamide gel $(10 \%$ for VEGF-R2, Vascular endothelial growth factor receptor 2, and $7 \%$ for CD31 and VE-cadherin. After electrophoresis, the gels were blotted to nitrocellulose membranes. GAPDH was used as loading control. Western blots were performed by using primary antibodies for endothelial VEGFR2 markers with 1/1000 milk/TBST (Tris-Buffered Saline Tween 20 0.5\% from Cell Signaling Technology, UK); VE-cadherin with 1/1000 BSA (Bovine Serum Albumin/TBST from Abcam, USA); CD31 with 1/1000 BSA/TBST (Dako, France). The membranes were blocked with the blocking buffer TBS (Tris Buffer Saline) for $1 \mathrm{~h}$ at room temperature and incubated with primary antibodies under gentle shaking at $4^{\circ} \mathrm{C}$ overnight. After extensive washing by TBS, the membranes were incubated for $1 \mathrm{~h}$ at room temperature with secondary antibodies conjugated to horseradish peroxidase (HRP). HRP activity was detected by enhanced chemiluminescence (ECL, Santa Cruz Biotechnology, USA). Santa Cruz Luminol Reagent A \& B associated, will be oxidized by HRP in presence of hydrogen peroxide emitting the light. Densitometry of the obtained bands was estimated by ImageJ software.

\section{Evaluation of endothelial-like cells functionality in terms of LDL-uptaking assay}

Low-density lipoprotein (LDL)-uptake assay was performed as described previously. At day 15, WJ-MSCs seeded on collagen and PEMs architectures were incubated for $4 \mathrm{~h}$ at $37^{\circ} \mathrm{C}$ in RPMI 1640 without phenol red supplemented with $0.8 \mu \mathrm{g} /$ mL Dil-Ac-LDL (Tebu-bio, France) labeled with rhodamine. Cells were washed with RPMI 1640 without phenol red to remove Dil-Ac-LDL. They were then fixed with $4 \%$ paraformaldehyde and nuclei were counterstained using 4',6-diamidino-2-phenylindole DAPI. The cells were observed using fluorescence microscopy (Leica microscope, ${ }^{\star} 40$ ) after using the appropriate excitation and emission filters for Rhodamin B (554nmEx/571nmEm).

\section{Von Willebrand Factor (vWF) immunostaining}

After 15 days of endothelial differentiation, the WJ-MSCs seeded on collagen and PEMs architectures were analyzed to assess vWF expression. The cells were fixed by $4 \%$ paraformaldehyde, permeabilized with PBS/Triton X-100 $(0.1 \%)$ for $15 \mathrm{~min}$, blocked with $1 \% \mathrm{BSA}$ and stained by 
murine anti-vWF (1/100 Dako, France). After two washes with PBS, the appropriate secondary antibody labeled with Alexa-Fluor-488 (diluted at 1/100) was incubated for $30 \mathrm{~min}$ at $37^{\circ} \mathrm{C}$. The cells were then observed by fluorescence microscopy (Zeiss microscopy, $\times 630$ magnification) using the (485Ex/538Em) spectral line.

\section{Statistical analysis}

Data were presented as a mean \pm SEM for each condition. Each experiment was repeated independently three times $(n=3)$. Pairwise comparisons were performed using one-factor ANOVA with Fisher correction (Stat view IVs, Abacus Concepts Inc., Berkley, CA). Differences were considered significant for $\mathrm{p}$ (rejection level of the null-hypothesis of equal means) values $<0.05$.

\section{Results and discussion}

\section{Characterization of WJ-MSCS}

Morphological characterization of MSCs ( $4^{\text {th }}$ passage) was performed according to the criteria defined by the International Society for Cellular Therapy [25]. MCSs derived from WJ of three umbilical cords displayed a homogeneous fibroblast-like morphology. Cells were analyzed regarding the expression of specific molecular markers by Fluorescein-Activated Cell Sorting analysis and showed that WJMSCs and BM-MSCs were positive for CD105, CD73, and CD90, and negative for CD45, CD34, CD86, and HLA-DR. These data revealed that WJ-MSCs used in this study showed the typical MSC characteristics (Data not shown).

\section{Evaluation of endothelial markers expression at the mRNA and protein levels}

In order to evaluate the effect of different adhesion matrices on differentiation of WJ-MSCs in endothelial-like cells, we measured the expression of endothelial markers by q-PCR and Western Blot. The three endothelial-specific molecules CD31, VE-cadherin and VEGF-R2 (KDR) are known to play an important role in the endothelium maturation during angiogenesis process [26]. CD31, also known as platelet endothelial cell adhesion molecule-1 (PECAM-1), is a type I integral membrane glycoprotein that is expressed at high levels on early and mature endothelial cells, platelets, and most leukocyte subpopulations. PECAM-1 is known to have various roles in vascular biology including angiogenesis, platelet function, and thrombosis [27]. VEGF-R2 is expressed on vascular endothelial cells and lymphatic endothelial cells; it regulates vascular endothelial function. VEGF is an important growth factor for the endothelial differentiation [28]. The endothelial-specific cadherin, vascular endothelial cadherin (VE-cadherin) is required for vascular genesis and the repair of damaged vessels [29].

The mRNA and protein levels of the three endothelial specific markers CD31, VEGF-R2 (KDR) and VE-cadherin were analyzed by real-time qPCR and Western blot (Figures 1 and 2). Relative expression of the three molecules was analyzed at mRNA and protein levels, and expressed relative to appropriate HUVEC values. WJ-MSCs seeded on CHI/HA or collagen and incubated in EBM-2 did not express the three markers at the protein level whereas their expression at the mRNA level was barely detectable $(<1 \%$ of the levels found in HUVECs for CD31 and CDH5). In WJ-MSCs incubated in EGM-2 for 15 days, mRNA level was higher on CHI/ HA than on collagen for CD31 and KDR (increase by 67\%, and $79 \%$, respectively). However, only the KDR increase was statistically significant. At the protein level, KDR expression was higher on $\mathrm{CHI} / \mathrm{HA}$ relative to collagen (45\% increase), but this difference was not statistically significant. CD31 protein levels were unchanged between collagen and $\mathrm{CHI} /$ $\mathrm{HA}$, whereas $\mathrm{CDH} 5$ level was higher on $\mathrm{CHI} / \mathrm{HA}$ relative to collagen ( $4 \%$ increase), and the difference was statistically significant. The fold change between collagen and CHI/HA at mRNA level was more important than fold change at protein level. After 15 days of differentiation, the transcription of endothelial genes give rise to high levels of mRNA from these genes. The translation process might take more culture time, to produce similar levels of proteins.

Higher mRNA and protein expression of these three markers in differentiated WJ-MSCs seeded on CHI/HA could contribute to more pronounced endothelial differentiation as compared with differentiated WJ-MSCs seeded on collagen. However, collagen is a recommended surface, allowing MSCs chondrogenic and osteogenic differentiation after 21 days [30]. In our report, we have not detected expression of VEGF-R2 protein on the collagen surface; maybe we needed more than 15 days to notice the translation of VEGF-R2 gene.

The capacity to differentiate towards endothelial phenotype is a characteristic of mesenchymal stem cells [30-32], and our results showed that WJ-MSCs express endothelial markers at mRNA and protein levels after 15-day cultures in presence of endothelial growth factors. However, the main purpose of this study was to evaluate endotheliogenic potential of WJ-MSCs seeded onto CHI/HA scaffolds. First, we verified the endothelial potential of WJ-MSCs in monolayer culture conditions both in proliferation (data not shown) and differentiation media. In proliferation medium, no endothelial differentiation was observed during the entire experimental time (15 days), further confirming the stem-cell origin of isolated cells. In differentiation medium, RT-PCR and Western Blot confirmed a better endothelial potential of these cells on $\mathrm{CHI} / \mathrm{HA}$.

Our choice of the CHI/HA scaffold was based on some studies that demonstrated the efficacy of this natural scaffold in enhancing hMSCs differentiation into stromal cells. hMSCs were induced to differentiate to chondrogenic, osteogenic, and adipogenic phenotypes [33]. Recent studies have shown the potential of WJ-MSCs to differentiate towards cardiomyocytes using CHI/HA scaffolds [34]. In our study, we have demonstrated that WJ-MSCs are able to differentiate into endothelial cells on CHI/HA films. Therefore, we can deduce that a combination of these cells with this natural scaffold is advantageous for cardio-vascular tissue engineering. Same conclusive results were observed in healing of diabetic skin wound by the proliferation and differentiation of human umbilical cords mesenchymal stem cells (hUCMSCs) on the collagen/chitosan laser drilling acellular dermal matrix (CCLDADM) scaffold, a natural scaffold used in vivo [35]. 


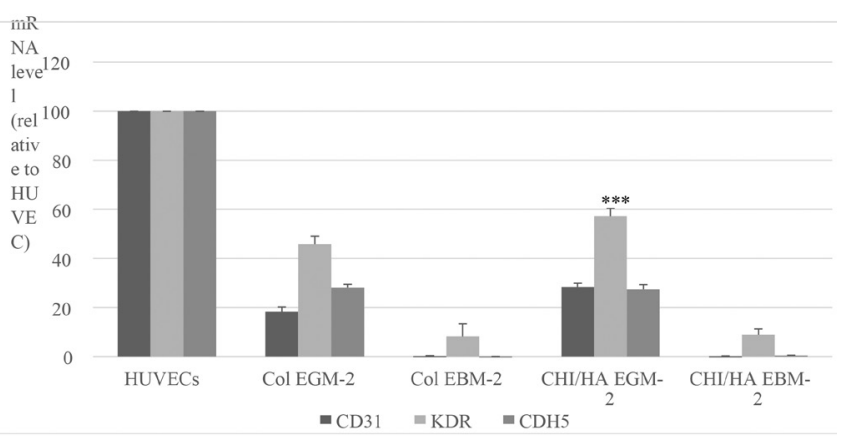

Figure 1. Investigation of endothelial cell markers at the mRNA level

Expression of the endothelial markers: CD31, CDH5 and KDR at the mRNA level was assessed in HUVECs endothelial-like cells seeded on collagen and CHI/HA in differentiation medium (EGM2) for 15 days. Results show the mRNA level normalized to the reference gene mRNA RP29 level and expressed relative to the mRNA level in HUVECs (set as 100) and non-treated cells (data not shown). Results represent the average of 3 independent experiments \pm SEM.

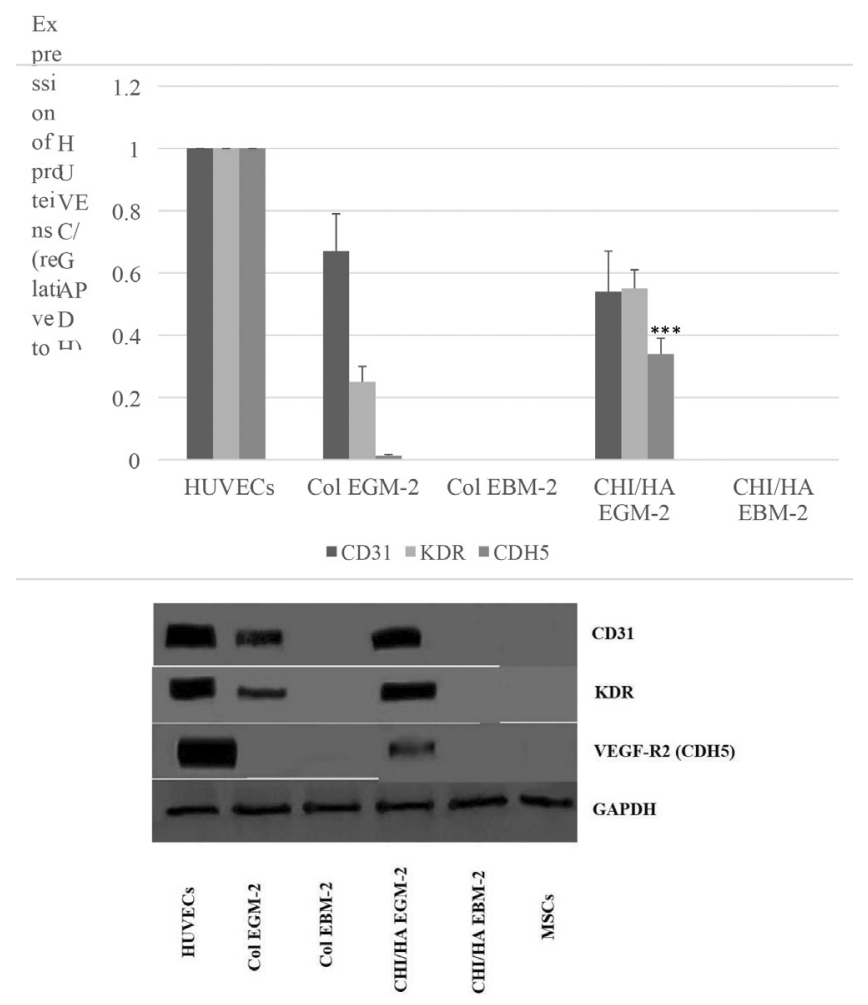

Figure 2. Studies of endothelial markers at the protein level

CD31, VEcadherin and VEGF-R2 blot quantifying for stimulated and unstimulated WJMSCs seeded on different culture surfaces after 15 days. Western blot normalization was performed to the expression of GAPDH. The expression in HUVECs was assumed for $100 \%$ (relative protein level $=1.0$ ). Results were expressed as the mean of 3 independent experiments \pm SEM. ${ }^{* *}: p<0,001$.

\section{Evaluation of endothelial-like cells functionality by LDL uptake assay}

LDL-uptake assay is applied for detection of functional endothelial cells. WJMSCs, when seeded on CHI/HA and collagen, captured DiIAcLDL to the cytoplasm after 4 hour-incubation in RPMI medium supplemented with DiI-Ac-LDL. However, MSCs were unable to uptake DiI-Ac-LDL after culturing in the growth medium as negative controls (Fig. 3). These results confirm that, after two weeks, WJ-MSCs seeded on $\mathrm{CHI} / \mathrm{HA}$ and collagen exhibit endothelial cell phenotype. In this respect, Gaffney et al. investigated lipoprotein uptake by means of flow cytometry and showed that the cells in a G2/M (mitosis) phase incorporated about $45 \%$ more Dil-AcLDL than those in a G1/S (latency) phase [36]. Higher DilAc-LDL uptake of endothelium-like cells on PEMs suggests that more cells are in the G2/M phase on PEMs, a feature of higher proliferation.

\section{Detection of endothelial-specific marker expres- sion: vWF (von Willebrand Factor) by immunocy- tochemistry}

Von Willebrand adherence factor (vWF) protein contributes to platelet function by mediating the initiation and progression of thrombus formation at the sites of vascular injury. Moreover, novel findings have been obtained on the link between regulation of VWF multimer size and microvascular thrombosis. This progress in basic research has provided critical information to define with greater precision the role of vWF in vascular biology and pathology, including its possible involvement in the onset of atherosclerosis and its acute thrombotic complications. Therefore we have used the expression of vWF as a functionality test of our endothelial-like cells [37]. The cells were examined for expression of endothelial-specific marker (vWF) by immunocytochemistry.

WJ-MSCs seeded on CHI/HA showed a high fluorescence specific to this marker after endothelial differentiation for 15 days. MSCs did not show any positive signal after they were cultured in the growth medium (EBM2) on the same scaffold, as negative controls. On collagen layer, the cells were not marked, that was predicted because they needed more culture time to express vWF protein (Fig. 4).

These promising results showed the possibility to combine the use of WJ-MSCs and CHI/HA films aiming for vascular tissue engineering, by evaluating the capacity of WJ-MSCs to differentiate into smooth muscle cells on $\mathrm{CHI} / \mathrm{HA}$, coating the surface of alginate hydrogels with $\mathrm{CHI} / \mathrm{HA}$ films, and enrolling them in order to form a tubular vascular graft.

These promising data showed that the combination of WJMSCs and CHI/HA may lead to brilliant results, regarding endothelial differentiation and angiogenesis. One may recommend using of these cells and materials for vascular tissue engineering and regeneration therapy. More studies can be done to evaluate the capacity of WJ-MSCs to differentiate into smooth muscle cells on $\mathrm{CHI} / \mathrm{HA}$, to coat the surface of alginate hydrogels with CHI/HA films and to enroll them, in order to form a tubular vascular graft. 

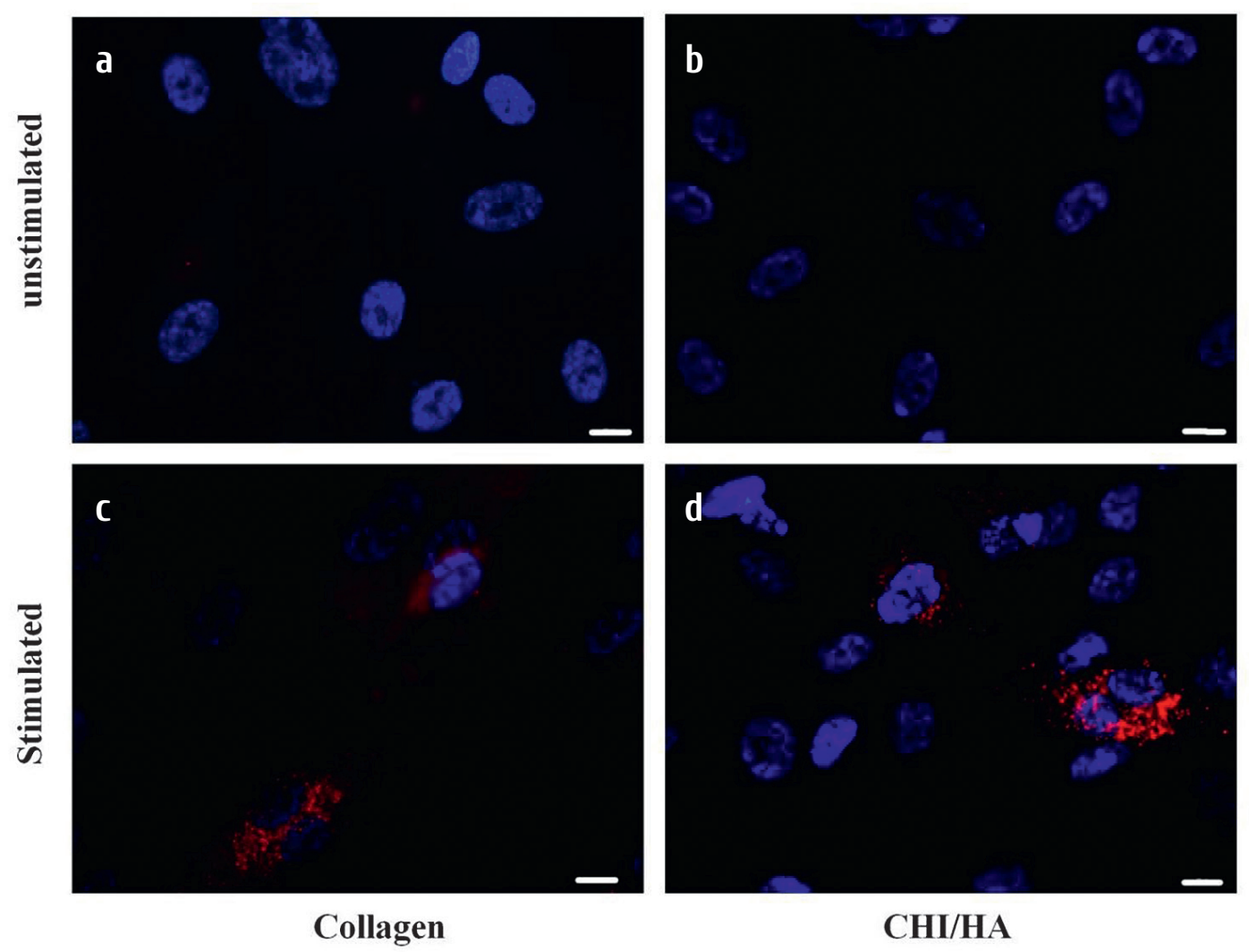

Figure 3. LDL-Uptake assay

WJ-MSCs cellular uptake of labeled acetylated LDLs. Double immunofluorescence of nuclei (blue) and for DI-Ac-LDLs (red) for unstimulated $(a, b)$ and stimulated $(c, d)$ WJMSCs after 15 days of culture on collagen and CHI/HA. Internalized labels were detected by Leica fluorescence microscopy (objective ${ }^{\star} 40$ oil).

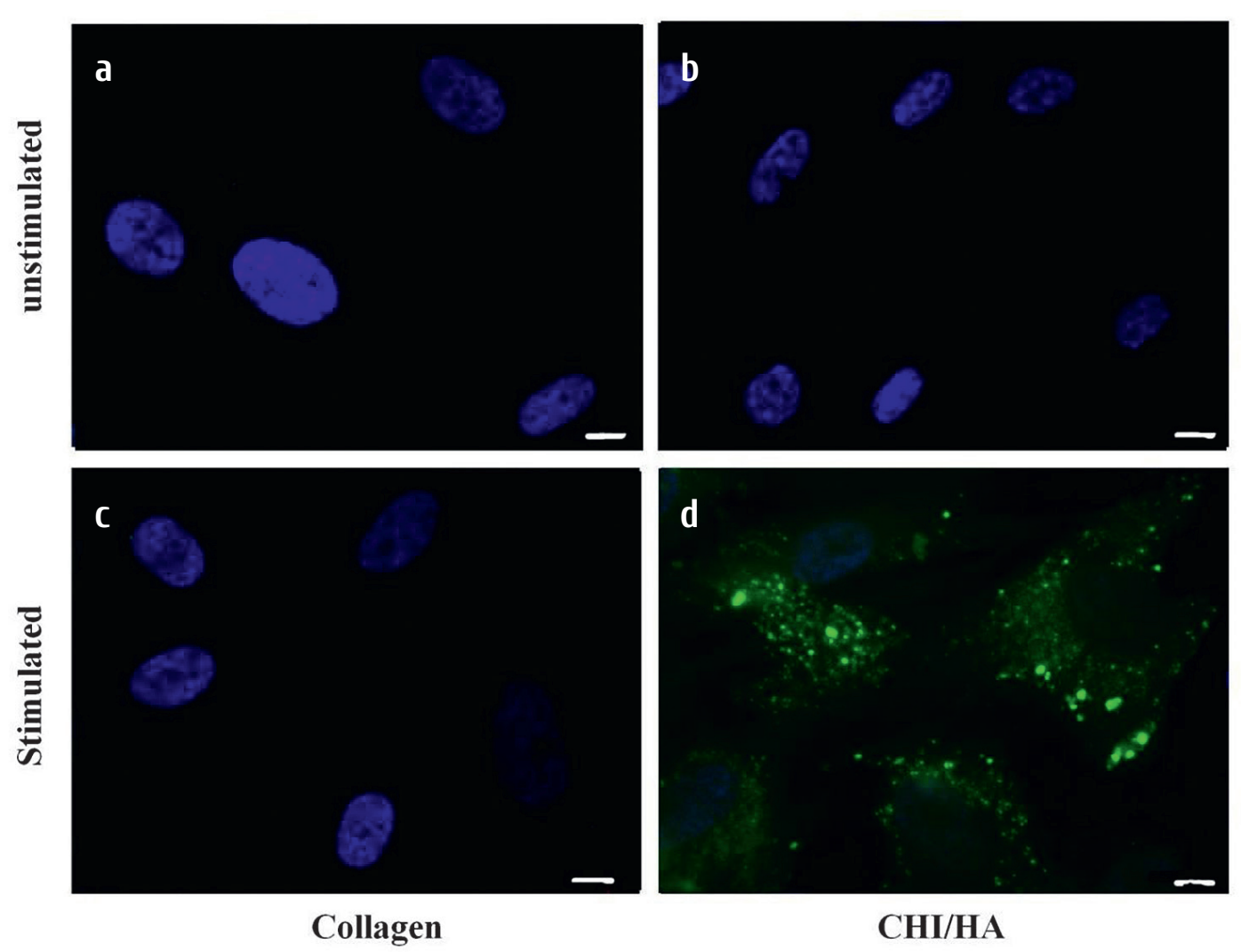

Figure 4: vWF immunostaining

Double immunofluorescence staining for nuclei (blue), and for prothrombogenic von Willebrand Factor for stimulated (a, b) and unstimulated (d, e) WJ-MSCs after 15 days of culture on collagen and $\mathrm{CHI} / \mathrm{HA}$ (Zeiss Microscope, objective 63 oil). N=3. 


\section{Conclusion}

These first quite encouraging results showed that it is possible to obtain CEs-like in a non-traumatic way (from Wharton's jelly of human umbilical cords) and in a short time (15 days). Our technique, based on the use of polyelectrolyte films, could therefore be used in the field of vascular engineering for the development of functional vascular substitutes comprising an endothelium resulting from differentiation of mesenchymal stem cells, which would limit the risks of graft rejection and could be applied to patients who require vessel replacement.

\section{Acknowledgements}

The authors would like to thank Al Hanan Hospital for providing the umbilical cords used in our researches and Azm \& Saadeh society for funding this work.

The authors have no conflicts of interest to declare.

Ethical Statement: The research work was approved by the ethical committee of the Lebanese University, Centre Azm for research in Applied Biotechnology and the ethical Committee of Al Hanan Hospital-Tripoli, Lebanon.

\section{References}

1. Viles-Gonzalez JF, Fuster V, Badimon JJ. Atherothrombosis: a widespread disease with unpredictable and life-threatening consequences. Eur Heart J. 2004;25(14):1197-1207.

2. Kumar VA, Brewster LP, Caves JM, Chaikof EL. Tissue engineering of blood vessels: functional requirements, progress, and future challenges. Cardiovasc Eng Technol. 2011;2(3):137-148.

3. Erler P, Sweeney A, Monaghan JR. Regulation of Injury-Induced Ovarian Regeneration by Activation of Oogonial Stem Cells. Stem Cells. 2017;35(1):236-247.

4. Sherman SE, Kuljanin M, Cooper TT, Putman DM, Lajoie GA, Hess DA. High aldehyde dehydrogenase activity identifies a subset of human mesenchymal stromal cells with vascular regenerative potential. Stem Cells. 2017;35(6):15421553.

5. Phinney DG, Pittenger MF. Concise review: MSC-derived exosomes for cell-free therapy. Stem Cells. 2017;35(4):851858.

6. Xu Y, Huang S, Ma K, Fu X, Han W, Sheng Z. Promising new potential for mesenchymal stem cells derived from human umbilical cord Wharton's jelly: sweat gland cell-like differentiative capacity. J Tissue Eng Regen Med. 2012;6(8):645654 .

7. Pittenger MF, Mackay AM, Beck SC, Jaiswal RK, Douglas R, Mosca JD, et al. Multilineage potential of adult human mesenchymal stem cells. Science. 1999;284(5411):143-147.

8. Dominici M, Le Blanc K, Mueller I, Slaper-Cortenbach I, Marini FC, Krause DS, et al. Minimal criteria for defining multipotent mesenchymal stromal cells. The International
Society for Cellular Therapy position statement. Cytotherapy. 2006;8(4):315-317.

9. Fong C-Y, Richards M, Manasi N, Biswas A, Bongso A. Comparative growth behaviour and characterization of stem cells from human Wharton's jelly. Reprod Biomed Online. 2007;15(6):708-718.

10. Kim MJ, Shin KS, Jeon JH, Lee DR, Shim SH, Kim JK, et al. Human chorionic-plate-derived mesenchymal stem cells and Wharton's jelly-derived mesenchymal stem cells: a comparative analysis of their potential as placenta-derived stem cells. Cell Tissue Res. 2011;346(1):53.

11. Troyer DL, Weiss ML. Concise review: Wharton's jelly-derived cells are a primitive stromal cell population. Stem Cells. 2008;26(3):591-599.

12. Abediankenari S, Ghasemi M. Generation of immune inhibitory dendritic cells CD4+T regulatory cells inducing by TGF- $\beta$. Iran J Allergy Asthma Immunol. 2009;8(1):25-30.

13. Nagamura-Inoue T, He H. Umbilical cord-derived mesenchymal stem cells: their advantages and potential clinical utility. World J Stem Cells. 2014;6(2):195.

14. Scott JE. Supramolecular organization of extracellular matrix glycosaminoglycans, in vitro and in the tissues. FASEB J. 1992;6(9):2639-2645.

15. Toole BP. Hyaluronan: from extracellular glue to pericellular cue. Nat Rev Cancer. 2004;4(7):528-539.

16. Rinaudo M. Main properties and current applications of some polysaccharides as biomaterials. Polym Int. 2008;57(3):397-430.

17. Muzzarelli RA. Chitosan composites with inorganics, morphogenetic proteins and stem cells, for bone regeneration. Carbohydr Polym. 2011;83(4):1433-1445.

18. Schanté CE, Zuber G, Herlin C, Vandamme TF. Chemical modifications of hyaluronic acid for the synthesis of derivatives for a broad range of biomedical applications. Carbohydr Polym. 2011;85(3):469-489.

19. Wang X, He J, Wang Y, Cui F-Z. Hyaluronic acid-based scaffold for central neural tissue engineering. Interface Focus. 2012;2(3):278-291.

20. Berger J, Reist M, Mayer JM, Felt O, Gurny R. Structure and interactions in chitosan hydrogels formed by complexation or aggregation for biomedical applications. Eur J Pharm Biopharm. 2004;57(1):35-52.

21. Urbich C, Dimmeler S. Endothelial progenitor cells: characterization and role in vascular biology. Circ Res. 2004;95(4):343-353.

22. Dennaoui H, Chouery E, Rammal H, Abdel-Razzak Z, Harmouch C. Chitosan/hyaluronic acid multilayer films are biocompatible substrate for Wharton's jelly derived stem cells. Stem Cell Investig. 2018;5.

23. Jaffe EA, Nachman RL, Becker CG, Minick CR. Culture of human endothelial cells derived from umbilical veins. Identification by morphologic and immunologic criteria. J Clin Invest. 1973; 52(11):2745-56. 
24. Rammal H, Harmouch C, Maerten C, Gaucher C, Boulmedais F, Schaaf P, et al. Upregulation of endothelial gene markers in Wharton's jelly mesenchymal stem cells cultured on polyelectrolyte multilayers. J Biomed Mater Res A. 2017;105(1):292-300.

25. Horwitz EM, Le Blanc K, Dominici M, Mueller I, Slaper-Cortenbach I, Marini FC, et al. Clarification of the nomenclature for MSC: The International Society for Cellular Therapy position statement. Cytotherapy. 2005;7(5):393-395.

26. Ferrara N. Vascular endothelial growth factor: basic science and clinical progress. Endocr Rev. 2004;25(4):581-611.

27. Woodfin A, Voisin M-B, Nourshargh S. PECAM-1: a multifunctional molecule in inflammation and vascular biology. Arterioscler Thromb Vasc Biol. 2007;27(12):2514-2523.

28. Li L, Liu H, Xu C, Deng M, Song M, Yu X, et al. VEGF promotes endothelial progenitor cell differentiation and vascular repair through connexin 43. Stem Cell Res Ther. 2017; 8(1):237.

29. Gory-Fauré S, Prandini M-H, Pointu H, Roullot V, Pignot-Paintrand I, Vernet $M$, et al. Role of vascular endothelial-cadherin in vascular morphogenesis. Development. 1999;126(10):2093-2102.

30. Goodwin HS, Bicknese AR, Chien SN, Bogucki BD, Oliver DA, Quinn CO, et al. Multilineage differentiation activity by cells isolated from umbilical cord blood: expression of bone, fat, and neural markers. Biol Blood Marrow Transplant. 2001;7(11):581-588.

31. Strem BM, Zhu M, Alfonso Z, Daniels EJ, Schreiber R, Begyui R, et al. Expression of cardiomyocytic markers on adipose tissue-derived cells in a murine model of acute myocardial injury. Cytotherapy. 2005;7(3):282-291.

32. Seo MJ. Suh SY, Bae YG, Jung JS. Differentiation of human adipose stromal cells into hepatic lineage in vitro and in vivo. Biochem Biophys Res Commun. 2005;328(1):258-264.

33. Lindborg BA, Brekke JH, Scott CM, Chai YW, Ulrich C, Sandquist L, et al. A chitosan-hyaluronan-based hydrogel-hydrocolloid supports in vitro culture and differentiation of human mesenchymal stem/stromal cells. Tissue Eng Part A. 2015;21(11-12):1952-62.

34. Rabbani S, Soleimani M, Imani M, Sahebjam M, Ghiaseddin A, Nassiri SM, et al. Regenerating Heart Using a Novel Compound and Human Wharton Jelly Mesenchymal Stem Cells. Arch Med Res. 2017;48(3):228-37.

35. 35. Han Y, Sun T, Han Y, Lin L, Liu C, Liu J, et al. Human umbilical cord mesenchymal stem cells implantation accelerates cutaneous wound healing in diabetic rats via the Wnt signaling pathway. Eur J Med Res. 2019;24(1):10.

36. Gaffney J, West D, Arnold F, Sattar A, Kumar S. Differences in the uptake of modified low density lipoproteins by tissue cultured endothelial cells. J Cell Sci. 1985;79(1):317325.

37. Ruggeri ZM. Von Willebrand factor, platelets and endothelial cell interactions. J Thromb Haemost. 2003;1(7):1335-1342. 


\title{
Эндотелиальная дифференцировка мезенхимных стволовых клеток из соединительной ткани пуповины (желе Вортона) на многослойных пленках из хитозана/гиалуронинана
}

\author{
Хана Деннауи ${ }^{1}$, Элиана Шуэри ${ }^{2}$, Шаза Хармуш ${ }^{1}$ \\ 1 Лаборатория прикладной биотехнологии: биомолекулы, биотерапия и биопроцессы, научно-прикладной центр \\ биотехнологии AZM, докторская школа науки и технологий, Ливанский университет, Триполи, Ливан \\ ${ }^{2}$ Отделение медицинской генетики, факультет медицины, университет Св. Иосифа (USJ), Мар-Микаэл, Бейрут, Ливан
}

\section{Резюме}

Простота заготовки мезенхимных стволовых клеток из желе Вортона (МСК-ЖВ), выраженная пластичность дифференцировки и низкая иммуногенность делают их удобным средством аллогенной клеточной терапии. Целью данного исследования было изучение способности к дифференцировке в эндотелиоподобные клетки МСК-ЖВ, культивированных на гиалуронан-хитозановых (ГХ) многослойных носителях.

\section{Материалы и методы}

В этой работе мы проводили дифференцировку МСК-ЖВ в ангиогенном направлении с применением полиэлектролитной многослойной пленки в качестве субстрата. МСК-ЖВ культивировали на ГХ-многослойной пленке и стимулировали факторами культуральной среды EGM-2 ${ }^{\circledR}$. Коллаген типа I использовали в качестве контрольного субстрата. Определяли экспрессию специфических мРНК, а именно: CD31, рецептора фактора роста сосудистого эндотелия типа 2 (VEGF2) и эндотелиального сосудистого кадхерина (VE), наряду с уровнями абсорбции Dil-ацетилированного липопротеина низкой плотности и экспрессией белкового фактора Виллебранда.

\begin{abstract}
Результаты
Выделенные МСК-ЖВ имели типичную морфологию фибробластоподобных клеток. Уровни мРНК, кодирующих CD31 и KDR были выше после культивирования на ГХ-субстрате, нежели на коллагеновом покрытии, при достоверном повышении экспрессии KDR. На уровне белков, показана тенденция к повышению уровней $\mathrm{KDR}$ и $\mathrm{CDH} 5$ после инкубации на ГХ-субстрате, по сравнению с коллагеном. Кроме того, МСК-ЖВ, культивированные на ГХ, имели высокие уровни экспрессии эндотелиальных маркеров после 15 суток культивирования в среде ЕGM-2 .
\end{abstract}

\section{Выводы}

В данной работе мы сообщаем о новом биосовместимом субстрате, который способствует дифференцировке МСК-ЖВ в эндотелиоподобные клетки. Разработка этого субстрата является новым подходом в тканевой инженерии для создания аллогенных сосудистых трансплантатов.

\section{Ключевые слова}

Мезенхимные стволовые клетки, желе Вортона, дифференцировка, эндотелий, хитозан, гиалуроновая кислота, многослойный субстрат, тканевая инженерия. 